Dhaka Univ. J. Biol. Sci. 27(2): 191-200, 2018 (July)

\title{
WATER QUALITY AND POTAMOPLANKTON OF THE RIVER BURIGANGA AND GOMTI: A COMPARISON
}

\author{
Mohammad Azmal Hossain Bhuiyan* and Moniruzzaman KhondKer \\ Department of Botany, University of Dhaka, Dhaka-1000, Bangladesh
}

Key words: Physical factors, Chemical factors, Phytoplankton

\begin{abstract}
The studied section of the river Buriganga besets with urban catchment contained higher values of $\mathrm{pH}$, alkalinity, $\mathrm{CO}_{2}$, conductivity, TDS, SRP, SRS and $\mathrm{NO}_{3}-\mathrm{N}$ concentration compared to its counterpart, namely a section of the river Gomti having rural catchment characteristics. The mean values for a period of six months for the river Buriganga were 8.34, $1.48 \mathrm{meq} \Lambda, 8.49 \mathrm{mg} \Lambda, 686 \mu \mathrm{S} / \mathrm{cm}$, $155.17 \mathrm{mg} \Lambda, 493 \mu \mathrm{g} \Lambda, 36.07 \mathrm{mg} \Lambda$ and $810.28 \mu \mathrm{g} \Lambda$ for $\mathrm{pH}$, alkalinity, $\mathrm{CO}_{2}$, conductivity, TDS, SRP, SRS and $\mathrm{NO}_{3}-\mathrm{N}$, respectively. While the same for the river Gomti was 7.86, $1.18 \mathrm{meq} \Lambda, 5.42 \mathrm{mg} \Lambda, 284.44 \mu \mathrm{S} / \mathrm{cm}, 79.91 \mathrm{mg} \Lambda, 188.37 \mu \mathrm{g} \Lambda$, $26.41 \mathrm{mg} \Lambda$ and $203.99 \mu \mathrm{g} \Lambda$, respectively for $\mathrm{pH}$, alkalinity, $\mathrm{CO}_{2}$, conductivity, TDS, SRP, SRS and $\mathrm{NO}_{3}-\mathrm{N}$. In the river Gomti, the concentration of DO was better $(7.87 \mathrm{mg} /$ ) compared to that of river Buriganga $(5.53 \mathrm{mg} /)$. Because of a hilly origin of the river Gomti and availability of sediments in its water, the underwater light climate was poor compared to the river Buriganga. The Secchi depth recorded for Gomti and Buriganga were 0.26 and $0.54 \mathrm{~m}$, respectively. Both the rivers were found diatom dominant in terms of population but the species prevailed were different. Fragillaria virescens Ralfs was the dominant diatom of the river Buriganga. Its density ranged from $6.5-11.09 \times 10^{5}$ ind 1 which was the highest compared to the population of all other groups of potamoplankton. In Gomti another diatom namely, F. pinnata Ehrenberg was dominant and the density of which ranged from $8.45-12.65 \times 10^{5}$ ind 1 . Community structure of the potamoplankton revealed 30 species from the river Buriganga and 22 species from Gomti. The study reveals that relatively higher concentration of nutrients prevails in the water of the river course having urban catchment characters compared to the rural ones.
\end{abstract}

\section{Introduction}

More than 3\% of the total area of Bangladesh is riverine which shares ca. $13 \%$ of total fresh water resources. The total network of rivers in Bangladesh comprises $24000 \mathrm{~km}$ in length having widths ranging from $5-10 \mathrm{~km}$. The river ecosystems of Bangladesh playing a vital role towards irrigation, domestic water use, navigation and fisheries. Moreover, the phytoplankton of the river ecosystems commonly called potamoplankton, is an useful community of organisms which put energy in the base of grazing food chain

*Author for correspondence: 〈bhuiyan.azmal@gmail.com>. 
upon which the primary consumer the zooplankton and the planktivorous fishes depend ${ }^{(1)}$. At present $30 \%$ of the country's total inland capture fisheries comes from rivers and a vast majority of population depend upon river waters for a variety of their uses. However, the physicochemical and biological quality of water along with the level of pollutants being contaminated is a common concern to the users.

Physicochemical and biological study on the urban sections of many rivers has already been studied ${ }^{(2-5)}$. Status and effects of industrial pollution were studied for Buriganga, Karnafully, Mathabanga ${ }^{(6-7)}$ and some other rivers ${ }^{(8)}$. Besides, pollution by organic matter of domestic origin was also studied for Buriganga ${ }^{(9-10)}$ and for Karnafully rivers ${ }^{(11)}$.

Gomti is a hilly river having a strong current. Its flow varies from $100-20,000$ cusec at Comilla. During the rainy season, its average width is about $100 \mathrm{~m}$ and becomes full from bank to bank with strong current. But during the winter it shrinks and becomes fordable at most places. In a year of normal rainfall the river rises to above $1.5 \mathrm{~m}$ than the level of the surrounding areas. Flash floods are common phenomena of this river and it occurs at regular intervals. Previously it was known as the 'Sorrow of Comilla Town'. The Bangladesh Water Development Board (BWDB) has taken several measures to tame the river and save Comilla town. During the flood of 1974, Gomti moved about $45 \mathrm{~km}$ upward and was used to fall into the river Meghna at Daudkandi. This changed course of the river resulted very adverse effects on trades and domestic water supply and irrigation near Daudkandi for dying the down streams of the abandoned river course. Two published limnological records on the river Gomti do prevail in Bangladesh(12-13).

Most of the rivers in Bangladesh pass through the land mass and finally fall into the Bay of Bengal resulting in a series of complex changes in sedimentation and erosion patterns. Rivers passing urban centers are invariably used as depositories for untreated domestic waste, sewage and industrial pollutants all of which can seriously reduce the quality of downstream surface waters and ground waters and not only affect aquatic life including fish but may also pose problems in terms of human health. On the other hand, a fluviatile section passing through the rural and agricultural settlements could have a different pattern of its physicochemical water quality. The aim of the present investigation was to compare the physicochemical water quality and community structure of potamoplankton of two locations of rivers having urban and rural catchment characters.

\section{Materials and Methods}

Sections of the river Buriganga adjacent to Dhaka Metropolis $\left(23.8103^{\circ} \mathrm{N}, 90.4125^{\circ} \mathrm{E}\right)$ and Gomti of Comilla $\left(23.4619^{\circ} \mathrm{N}, 91.1869^{\circ} \mathrm{E}\right)$ have been selected as having urban and rural catchments, respectively. The sampling stations for the river Buriganga were Alir Ghat, Kellar Mor Bazar and Swari Ghat. For the river Gomti, the sampling stations were 
Kaptan Bazar, Chandpur Bridge and Tikkar Char Bridge. Morphometric and physiographic information of the studied rivers are available elsewhere ${ }^{(3,12-14)}$.

The collection of samples for the present study was carried out from May to October 2011 between 09:00 and 11:00 a.m. On each occasion, a boat was used to reach the sampling stations and in situ measurements of relevant parameters were carried out. Methodologies applied for determining the physicochemical and biological parameters have been published earlier ${ }^{(15-16)}$.

\section{Results and Discussion}

Each variable measured from three different stations for each river were pooled to mean and plotted against each month (Figs 1 - 2). Air and water temperature showed almost similar relationship in both the rivers(17). In Buriganga, air and water temperature peaked in August and fell in September but in Gomti this relationship followed the months of September and October (Fig. 1a,b). It means the peak temperature in Buriganga occurred a month ahead compared to Gomti. Water depth of the study stations of the river Buriganga varied from $8.0-11.8 \mathrm{~m}$, but for Gomti this ranged from 5.0-7.5 m. Both the rivers showed highest depth in July (Fig. 1c). The depth of visibility of water measured as Secchi depth was higher in Buriganga (0.5-0.62 m) than Gomti (0.2$0.38 \mathrm{~m}$ ). Maximum water transparency occurred in August in Buriganga, in Gomti it was in September (Fig. 1d). In May, water of both the rivers was least transparent. $\mathrm{pH}$ fell in an alkaline range in both the rivers and followed almost same pattern of variation (Fig. 1e). Higher conductivity values $(635-750 \mu \mathrm{S} / \mathrm{cm})$ were recorded for the river Buriganga than Gomti (250-350 $\mathrm{\mu S} / \mathrm{cm}$ ), values were high in May for both the rivers (Fig. 1f).

Total dissolved solids (TDS), free carbon dioxide, soluble reactive phosphorus (SRP) and nitrate nitrogen were high in the river Buriganga compared to Gomti (Fig. 2 a, d, e). The trend of fluctuation for TDS followed an identical patter for both the studied rivers i.e., a gradual fall in the concentration of TDS was observed from May of October of the studied year 2011. However, in the river Buriganga and for $\mathrm{CO}_{2}$, after falling the concentration in the first three months of the study it did start increasing (Fig. 2b). Similar trend was also found in case SRP in the same river. The SRS concentration in both the studied rivers showed a reverse pattern of temporal fluctuations among them (Fig. 2f). Similar pattern was also found for alkalinity in both the rivers (Fig. 2b).

Physical water quality parameters like air and water temperature did not vary much between the two rivers (Table 1). However the mean water transparency value was $2 \times$ higher in Gomti than Buriganga. Gomti has an origin of hilly region and as a result its water carrying more sediments than Buriganga. So, the underwater light climate proves to be better in Buriganga than Gomti. When compared the $\mathrm{pH}$ value of two rivers, water of the river Buriganga was found little more alkaline than Gomti (Table 1). Conductivity and TDS of the river Buriganga were 2.41 and 1.94 times higher than Gomti. Minor 
variation but at a higher scale was seen in case of free carbon dioxide and alkalinity in the river Buriganga than Gomti (Table 1). The concentration of dissolved oxygen in the river Gomti was satisfactory $(7.87 \mathrm{mg} \Lambda)$ compared to the river Buriganga (5.53 mg 1 ) ${ }^{18)}$. The concentration of nitrate nitrogen in the river Buriganga was nearly $4 \times$ higher compared to its concentration in the river Gomti (Table 1).
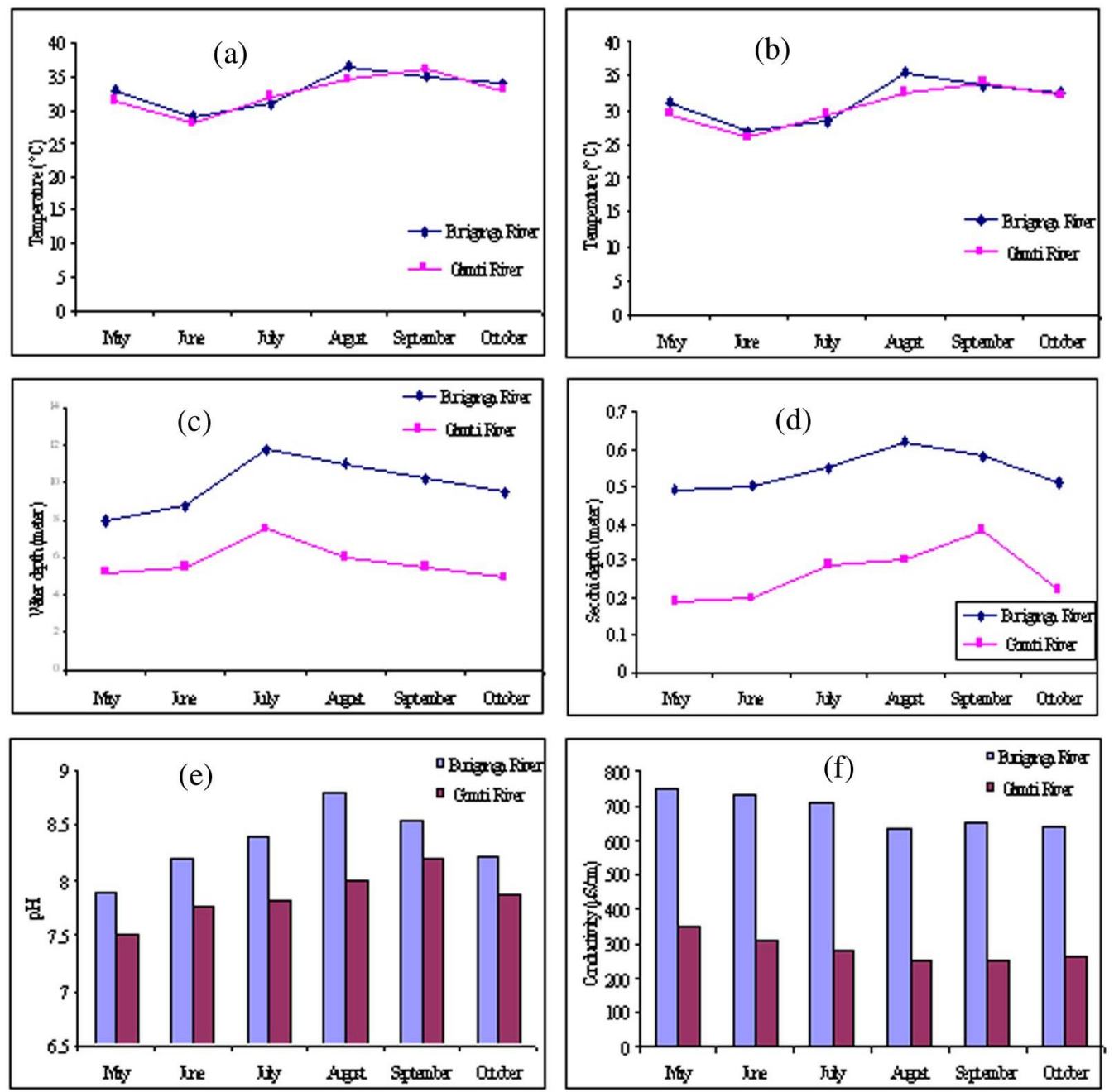

Figs 1a-f. Comparison of monthly values of different environmental parameters of the river Gomti and Buriganga. (a) Air temperature, (b) water temperature, (c) water depth, (d), secchi depth, (e) $\mathrm{pH}$ and (f) conductivity.

Tables 2 and 3 reveal the qualitative and quantitative aspects of dominant flora of potamoplankton of the studied rivers. The river Buriganga supports a total of 30 species while the river Gomti supporting 20 species of potamoplankton ${ }^{(19)}$. This has happened 
because of the light climate of the latter habitat is $48 \%$ lower than the former. The concentration of nitrogen and phosphorus is also lower in the latter river (Table 1). Qualitatively the river Gomti was found to be dominated by diatoms (20) but on the other hand the river Buriganga supported a luxuriant content of both diatoms and euglenoid algae (Table 2). The distributional pattern of potamoplankton of the river Buriganga to
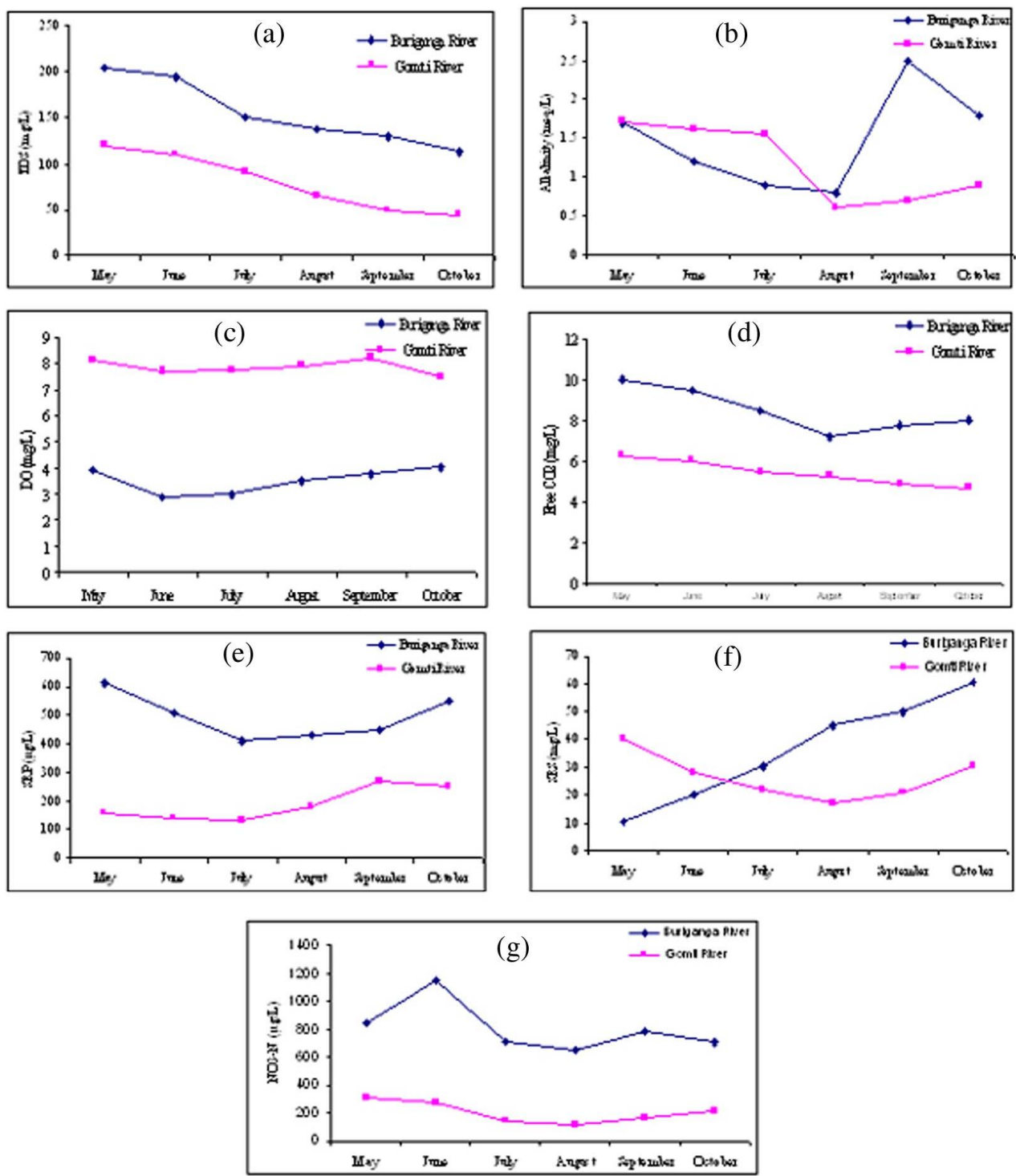

Figs 2a-g. Fluctuations of monthly mean values of some water quality parameters of the river Gomti and Buriganga. (a) TDS, (b) alkalinity, (c) DO, (d) free $\mathrm{CO}_{2}$, (e) SRP, (f) SRS, (g) $\mathrm{NO}_{3}-\mathrm{N}$ of both the rivers during the course of study. 
Table 1. A comparison of mean values of different environmental and biological parameters between the Gomti river and Buriganga river.

\begin{tabular}{lllll}
\hline Parameters & \multicolumn{2}{c}{ Gomti River } & \multicolumn{2}{c}{ Buriganga River } \\
\cline { 2 - 5 } & Mean & $\pm \mathrm{Sd}$ & Mean & $\pm \mathrm{Sd}$ \\
\hline Air temperature $\left({ }^{\circ} \mathrm{C}\right)$ & 32.50 & 2.76 & 33.83 & 2.73 \\
Water temperature $\left({ }^{\circ} \mathrm{C}\right)$ & 30.58 & 2.85 & 31.33 & 3.17 \\
Water depth $(\mathrm{m})$ & 5.78 & 0.91 & 9.88 & 1.41 \\
Secchi depth $(\mathrm{m})$ & 0.26 & 0.073 & 0.54 & 0.051 \\
$\mathrm{pH}$ & 7.86 & 0.23 & 8.34 & 0.31 \\
$\mathrm{Conductivity}(\mu \mathrm{S} / \mathrm{cm})$ & 284.44 & 38.97 & 686.00 & 50.78 \\
$\mathrm{TDS}(\mathrm{mg} /)$ & 79.91 & 31.76 & 155.17 & 36.89 \\
$\mathrm{CO}(\mathrm{mg} /)$ & 5.42 & 0.62 & 8.49 & 1.07 \\
$\mathrm{Alkalinity}(\mathrm{meq} /)$ & 1.18 & 0.50 & 1.48 & 0.64 \\
$\mathrm{DO}(\mathrm{mg} /)$ & 7.87 & 0.26 & 5.53 & 0.49 \\
$\mathrm{SRP}(\mu \mathrm{g} /)$ & 188.33 & 58.45 & 493 & 77.29 \\
$\mathrm{SRS}(\mathrm{mg} /)$ & 26.41 & 8.23 & 36.07 & 19.10 \\
$\mathrm{NO} 3-\mathrm{N}(\mu \mathrm{g} /)$ & 203.99 & 78.96 & 810.28 & 179.82 \\
\hline
\end{tabular}

different algal classes reported earlier followed 56.19\% Chlorophyceae, 29.90\% Bacillariophyceae, $10.31 \%$ Cyanophyceae and $1.03 \%$ Euglenophyceae ${ }^{(4)}$. But the present study reports a changed community pattern, whereby Euglenophyceae getting dominant along with Chlorophyceae. The density of the potamoplankton belonging to the bluegreen, green and cryptomonads for both Buriganga and Gomti were almost same (Table 2). Fragillaria virescens Ralfs was the dominant diatom of the river Buriganga. Its density ranged from $6.5-11.09 \times 10^{5}$ ind $\Lambda$ which was the highest compared to the population of all other groups of potamoplankton (Table 2). In Gomti another diatom namely, F. pinnata Ehrenberg was dominant and the density of which ranged from $8.45-12.65 \times 10^{5}$ ind $\Lambda$ (Table 2). Highest number of species 8 in each was recorded from Euglenophyta and Chlorophyta in the river Buriganga. While in the river Gomti the above mentioned groups of potamoplankton were represented by 5 and 6 species, respectively (Table 2).

In the present comparative study between the two rivers, one having an urban (Buriganga) and the other having a rural (Gomti) catchment character, it has been revealed that the water of the former has relatively higher values of Secchi depth, TDS, conductivity, alkalinity, $\mathrm{pH}, \mathrm{CO}_{2}$, SRS, SRP and $\mathrm{NO}_{3}-\mathrm{N}$ (Table 1). However, in terms of $\mathrm{DO}$, Gomti showed a better condition. The mean value of DO from Gomti over the study period was $7.87 \mathrm{mg} /$ while in Buriganga the value was $5.53 \mathrm{mg}$. The qualitative structure of the potamoplankton community of the rivers was not identical at least for the dominant species. However, diatoms yielded in high densities in both the rivers. Two different species of pinnate diatom (Fragillaria) showed their abundance to the highest densities in both the rivers. From this study it could be concluded that the urban section (Buriganga) of the studied rivers contain higher contaminants than the rural section, as it 
Table 2. Qualitative and quantitative $\left(\times 10^{5} \mathrm{ind} / \mathrm{l}\right)$ aspects of dominant phytoplankton in the river Burigananga, Dhaka.

\begin{tabular}{|c|c|c|c|c|c|c|c|}
\hline $\begin{array}{l}\text { Sl. } \\
\text { No. }\end{array}$ & $\begin{array}{l}\text { Taxa with } \\
\text { systematic position }\end{array}$ & May & June & July & Aug. & Sept. & Oct. \\
\hline & CYANOPHYTA & & & & & & \\
\hline & Chroococcales & & & & & & \\
\hline 1 & Merismopedia punctata Meyen & 2.0 & 1.75 & 3.25 & 1.80 & 1.70 & 1.5 \\
\hline 2 & $\begin{array}{l}\text { Merismopedia trolleri Bachmann } \\
\text { Nostocales }\end{array}$ & 2.25 & 2.0 & 2.75 & 2.25 & 1.98 & 1.25 \\
\hline 3 & Oscillatoria salina Biswas & 1.22 & 1.23 & 1.55 & 1.29 & 1.22 & 0.95 \\
\hline 4 & Spirulina laxa G.M. Smith & 2.0 & 1.76 & 2.15 & 1.74 & 1.77 & 1.50 \\
\hline 5 & $\begin{array}{l}\text { Arthrospira platensis (Nordst.) } \\
\text { Gomont }\end{array}$ & 2.15 & 2.0 & 1.98 & 2.11 & 1.96 & 1.33 \\
\hline 6 & $\begin{array}{l}\text { Oscillatoria limnetica Lemm. } \\
\text { CHRYSOPHYTA } \\
\text { Bidulphiliales }\end{array}$ & 2.10 & 1.80 & 1.75 & 1.85 & 1.72 & 1.0 \\
\hline 7 & $\begin{array}{l}\text { Melosira granulata var. angustissima } \\
\text { Müll. } \\
\text { Bacillariales }\end{array}$ & 1.19 & 1.10 & 1.15 & 1.13 & 1.00 & 0.5 \\
\hline 8 & Fragilaria virescens Ralfs & 10.25 & 9.85 & 11.09 & 10.00 & 8.98 & 6.5 \\
\hline 9 & $\begin{array}{l}\text { Synedra ulna (Nitzsch.) Ehr. var. } \\
\text { oxyrhynchus (Kütz) O'Meara }\end{array}$ & 2.5 & 2.0 & 2.76 & 2.25 & 2.00 & 0.95 \\
\hline 10 & $\begin{array}{l}\text { Cyclotella meneghiniana Kütz. } \\
\text { EUGLENOPHYTA } \\
\text { Euglenales }\end{array}$ & 1.25 & 0.75 & 1.57 & 1.15 & 0.95 & 0.87 \\
\hline 11 & $\begin{array}{l}\text { Phacus pseudonorstedtii Pochm var. } \\
\text { minuscule (Conr.) Huber-Pestalozzi }\end{array}$ & 3.5 & 3.15 & 3.67 & 3.25 & 3.10 & 2.52 \\
\hline 12 & Phacus granum Drez. & 4.5 & 4.00 & 5.25 & 4.17 & 3.98 & 2.23 \\
\hline 13 & $\begin{array}{l}\text { Phacus acuminats var. granulata (Roll) } \\
\text { Huber-Pest. }\end{array}$ & 3.10 & 3.20 & 3.55 & 3.22 & 3.00 & 1.78 \\
\hline 14 & $\begin{array}{l}\text { Lepocinclis ovum var. dimidio- minor } \\
\text { (Delf.) Conrad. }\end{array}$ & 7.75 & 6.78 & 8.15 & 7.00 & 6.00 & 5.56 \\
\hline 15 & Lepocinclis texta (Duj.) Lemm. & 6.50 & 5.79 & 7.78 & 6.15 & 5.10 & 5.0 \\
\hline 16 & Lepocinclis salina Fritsch & 3.25 & 3.00 & 3.67 & 3.11 & 2.98 & 2.75 \\
\hline 17 & Lepocinclis teres fa. parvula Conr. & 3.12 & 2.77 & 3.44 & 2.95 & 2.57 & 1.97 \\
\hline 18 & $\begin{array}{l}\text { Trachelomonas volvocina var. punctata } \\
\text { Playfair } \\
\text { CHLOROPHYTA } \\
\text { Volvocales }\end{array}$ & 2.15 & 1.75 & 1.55 & 1.79 & 1.74 & 1.50 \\
\hline 19 & Pandorina morum (Muller) Bory & 2.0 & 1.98 & 2.75 & 2.00 & 1.80 & 1.60 \\
\hline 20 & Chlorogonium euchlorum Ehr. & 2.29 & 2.00 & 3.00 & 2.12 & 1.95 & 1.59 \\
\hline 21 & Pyrobotrys gracilis (Kors.) Kors. & 12.0 & 10.89 & 12.45 & 10.99 & 9.67 & 7.77 \\
\hline
\end{tabular}




\begin{tabular}{|c|c|c|c|c|c|c|c|}
\hline & Sphaeropleales & & & & & & \\
\hline 22 & $\begin{array}{l}\text { Monoraphidium griffithii (Berkeley) } \\
\text { Kom. Legn }\end{array}$ & 5.0 & 4.98 & 5.15 & 5.10 & 4.00 & 2.99 \\
\hline \multirow[t]{2}{*}{23} & $\begin{array}{l}\text { Monoraphidium arcuatum (Korsikov) } \\
\text { Hind. }\end{array}$ & 2.5 & 2.17 & 2.76 & 2.47 & 2.15 & 1.23 \\
\hline & Chlorococcales & & & & & & \\
\hline 24 & Coelastrum microporum Nägeli & 2.75 & 2.80 & 2.90 & 2.83 & 2.71 & 2.50 \\
\hline \multirow[t]{2}{*}{25} & $\begin{array}{l}\text { Closteriopsis longissima var. tropica } \\
\text { West and West }\end{array}$ & 1.0 & 0.89 & 0.1 .5 & 0.98 & 0.80 & 0.70 \\
\hline & Zygnematales & & & & & & \\
\hline \multirow[t]{3}{*}{26} & $\begin{array}{l}\text { Closterium venus Kg. var. crassum } \\
\text { Croasdale }\end{array}$ & 2.5 & 2.0 & 3.25 & 2.11 & 1.97 & 1.57 \\
\hline & Cryptophyta & & & & & & \\
\hline & Cryptomondales & & & & & & \\
\hline 27 & Cryptomonas ovata Ehr. & 3.25 & 3.15 & 3.25 & 3.16 & 3.00 & 2.45 \\
\hline 28 & Chilomonas acuta var. insignis Skuja & 2.15 & 1.98 & 2.44 & 1.99 & 1.90 & 0.70 \\
\hline 29 & Cryptomonas ovata Czosnowski & 2.11 & 2.14 & 2.10 & 2.15 & 2.11 & 1.67 \\
\hline 30 & Cryptomonas reflexa Skuja & 2.56 & 2.54 & 2.78 & 2.55 & 2.35 & 1.99 \\
\hline
\end{tabular}

Table 3. Qualitative and quantitative $\left(\times 10^{5} \mathrm{ind} / \mathrm{l}\right)$ aspects of dominant phytoplankton in the river Gomti, Comilla.

\begin{tabular}{|c|c|c|c|c|c|c|c|}
\hline $\begin{array}{l}\text { Sl. } \\
\text { No. }\end{array}$ & $\begin{array}{l}\text { Taxa with } \\
\text { systematic position }\end{array}$ & May & June & July & Aug. & Sept. & Oct. \\
\hline & CYANOPHYTA & & & & & & \\
\hline & Chroococcales & & & & & & \\
\hline 1 & Microsystis holsatica Lemm. & 3.5 & 3.00 & 3.88 & 3.22 & 2.70 & 1.45 \\
\hline 2 & $\begin{array}{l}\text { Microcystis robusta (Clark) } \\
\text { Nygaard }\end{array}$ & 2.35 & 2.45 & 2.79 & 2.55 & 2.22 & 1.97 \\
\hline 3 & $\begin{array}{l}\text { Microcystis flos-aquae (Wittr.) } \\
\text { Kirchner } \\
\text { Nostocales }\end{array}$ & 2.25 & 2.00 & 2.80 & 2.10 & 1.98 & 0.90 \\
\hline 4 & Oscillatoria limnetica Lemm. & 3.0 & 2.65 & 3.25 & 2.78 & 2.30 & 1.87 \\
\hline 5 & Lyngbya limnetica Lemm. & 3.5 & 3.47 & 4.25 & 3.49 & 3.25 & 2.56 \\
\hline 6 & $\begin{array}{l}\text { Anabaenopsis elenkinii V. V. } \\
\text { Miller } \\
\text { CHRYSOPHYTA } \\
\text { Bidulphiliales } \\
\text { Bacillariales }\end{array}$ & 2.85 & 2.75 & 3.00 & 2.95 & 2.50 & 1.34 \\
\hline 7 & Synedra ulna (Nitzsch) Ehr. & 7.57 & 6.98 & 8.00 & 7.00 & 6.00 & 5.10 \\
\hline 8 & Fragilaria pinnata Ehrenberg & 12.5 & 12.00 & 12.65 & 12.15 & 10.23 & 8.45 \\
\hline
\end{tabular}




\begin{tabular}{|c|c|c|c|c|c|c|c|}
\hline & EUGLENOPHYTA & & & & & & \\
\hline & Euglenales & & & & & & \\
\hline 9 & Lepocinclis teres fa.Parvula Conr. & 3.5 & 3.52 & 4.25 & 3.57 & 3.00 & 1.77 \\
\hline 10 & $\begin{array}{l}\text { Strombomons verrucosa var. } \\
\text { borystheniensis (Roll) Defl. }\end{array}$ & 2.15 & 1.96 & 2.89 & 1.98 & 1.56 & 0.98 \\
\hline 11 & $\begin{array}{l}\text { Trachelomonas volvocina } \\
\text { Ehrenberg }\end{array}$ & 3.5 & 3.25 & 4.00 & 3.50 & 3.44 & 2.67 \\
\hline 12 & $\begin{array}{l}\text { Trachelomonas oblonga var. } \\
\text { truncate Lemm. }\end{array}$ & 3.5 & 3.25 & 3.77 & 3.35 & 3.11 & 2.78 \\
\hline 13 & $\begin{array}{l}\text { Phacuspseudo nordstedtii Pochm. } \\
\text { var. minuscule (Conr.) Huber- } \\
\text { Pestalozzi } \\
\text { CHLOROPHYTA } \\
\text { Volvocales }\end{array}$ & 2.5 & 2.00 & 3.25 & 2.17 & 1.66 & 1.55 \\
\hline 14 & $\begin{array}{l}\text { Chlorogonium elongatum(Dang.) } \\
\text { France } \\
\text { Sphaeropleales }\end{array}$ & 3.5 & 3.25 & 3.85 & 3.27 & 3.00 & 2.00 \\
\hline 15 & $\begin{array}{l}\text { Monoraphidium arcuatum } \\
\text { (Korsikov) Hind. }\end{array}$ & 3.25 & 3.15 & 3.89 & 3.18 & 2.93 & 1.69 \\
\hline 16 & $\begin{array}{l}\text { Ankistrodesnmus falcatus var. } \\
\text { mirabilis (West and West) } \\
\text { Lemm. }\end{array}$ & 4.15 & 4.25 & 5.15 & 4.28 & 3.78 & 4.00 \\
\hline 17 & $\begin{array}{l}\text { Ankistrodesmus barnardi Kom. } \\
\text { Chlorococcales }\end{array}$ & 4.75 & 4.70 & 5.33 & 4.77 & 4.19 & 4.00 \\
\hline 18 & $\begin{array}{l}\text { Chlorococcum infusionum } \\
\text { (Schrank) Meneghini } \\
\text { Zygnematales }\end{array}$ & 3.5 & 3.48 & 4.25 & 3.50 & 2.50 & 2.23 \\
\hline 19 & $\begin{array}{l}\text { Closterium porrectum Nordst. } \\
\text { var. angustatum West \& West } \\
\text { Cryptophyta } \\
\text { Cryptomondales }\end{array}$ & 4.5 & 3.98 & 4.90 & 4.11 & 3.45 & 3.50 \\
\hline 20 & Cryptomonas ovata Ehr. & 3.5 & 3.25 & 3.80 & 3.28 & 2.78 & 2.53 \\
\hline 21 & $\begin{array}{l}\text { Rhodomonas lacustris Pascher et } \\
\text { Ruttner }\end{array}$ & 2.5 & 2.14 & 2.99 & 2.16 & 1.87 & 1.88 \\
\hline 22 & Rhodomonas minuta Skuja & 2.25 & 2.19 & 2.83 & 2.22 & 1.50 & 1.19 \\
\hline
\end{tabular}

is revealed by the higher concentration of nutrients and relatively low values of oxygen. The number of species from the potamoplankton was higher by only 8 more species in the urban section of the river Buriganga.

\section{References}

1. Reynolds CS 1984. The ecology of freshwater phytoplankton. Cambridge Univ. Press. Cambridge. pp. 384.

2. Islam AKMN, AKY Haroon and KM Zaman 1974. Limnological studies of the river Buriganga. I. Physical and chemical aspects. Dhaka Univ. Stud. Pt. B, 22(2): 99-111. 
3. Islam AKMN and KM Zaman 1975. Limnological studies of the river Buriganga. III. Biological aspect. J. Asiatic Soc. Bangladesh (Sci.) 1(1): 45-65.

4. Islam AKMN and AKY Haroon 1975. Limnological studies of the river Buriganga. II. Biological aspect. Dacca Univ. Stud. Pt. B, 21(1): 25-44.

5. Mahmood N, YSA Khan and MK Ahmed 1976. Studies on the hydrology of the Karnafully estuary. Asiatic Soc. Bangladesh (Sc.) 2(1): 51-58.

6. Alam AMS, KMA Malik, SZ Haider, M Amanullah and M Billah 1991. Environmental pollution with reference to effluents from sugar mills in Bangladesh: A case study. J. Bangladesh Chem. Soc. 4(2): 225-229.

7. Shekar HU, ME Haque, SA Hossain and Z Yusuf 1993. Environmental pollution due to effluents from sugar and sugar based industries in Bangladesh. Dhaka Univ. J. Biol. Sci. 2(2):209-213.

8. Anonymous 1992. Action Programme for the conservation of Wetlands in South and West Asia. AWB, Kuala Lumpur and IWRB, Slimbridge, pp. 1-32.

9. Ahmed MF 1993. The effect of bio-degradable organic pollutants on aquatic ecosystem of the River Buriganga. In: Hypertrophic and Polluted Freshwater Ecosystems: Ecological bases for water Resources Management (Tilzer MM and M Khondker eds.). Proc. Int. Symp. Limnol., Botany Dept. Dhaka Univ., Bangladesh. pp. 97-108.

10. Morshed MG, KMS Aziz, MS Islam and MR Khan 1985. Presence of coliform bacteria and their relative abundance in three sampling stations on Buriganga river. Bangladesh J. Microbiol. 2(1\&2): 6-10.

11. Patra RWR and MA Azadi 1987. Ecological studies on the planktonic organisms of the Halda river. Bangladesh J. Zool. 15(2): 109-123.

12. Khondker M and AKMH Talukder 1995. Limnological assessment of some water bodies within Gumti floodplain, Comilla. Dhaka Univ. J. Biol. Sci. 4(1): 51-58.

13. Kabir AKMN, S Ali and M Khondker 1996. Study on the zooplankton from the Gumti floodplain. Dhaka Univ. Biol. Sci. 5(2): 129-135.

14. Zerin L, A Gani and M Khondker 2017. Comparative water quality assessment of the river Buriganga near Dhaka metropolis. Bangladesh J. Bot. 46(2): 589-598.

15. Khondker M and G Abed 2013. Seasonality of phytoplankton productivity of the river Turag of Dhaka in relation to its water quality. Bangladesh J. Bot. 42(2): 287-294.

16. Khondker M, MA Alfasane, MS Islam, MAH Bhuiyan and A Goni 2010. Limnology of Lake Bogakine, Bandarban. Bangladesh J. Bot. 39(2): 153-159.

17. Bhuiyan MAH, Khondker M and Begum ZNT 2010a. Other side of the Ashulia wetland: A Limnological purview. Dhaka Univ. J. Biol. Sci. 19(1): 21-26.

18. Hasan, MK and Bhuiyan MAH 2013. A comparative study of water quality in the peripheral rivers of Dhaka City. Indian J. Human. 3(3): 1-9.

19. Bhuiyan MAH, Khondker M and Begum ZNT 2010b. Diversity in the pelagic plankton of Wetland Ashulia. J. Taxon. Biodiv. Res. 4: 9-16.

20. Bhuiyan, MAH and Khondker, M 2017. Seasonal variation of water quality of Dharma Sagar of Comilla City. Bangladesh J. Bot. 46(3): 971-979. 